\title{
Changes in the structure of fish assemblages in streams along an undisturbed-impacted gradient, upper Paraná River basin, Central Brazil
}

\author{
Alesandra Martins Dias ${ }^{1}$ and Francisco Leonardo Tejerina-Garro ${ }^{2}$
}

The João Leite River is located in the upper Paraná basin, Central Brazil. It drains areas covered by Cerrado vegetation interspersed with urban and agricultural areas. This study aims to asses changes of the fish assembleges structure along a undisturbed-impacted gradient in ten stream stretches using ecological descriptors, a similarity index and the abundancebiomass relationship (ABC curves). The fish were collected during the dry period using electrofishing gear in stretches of 50 $\mathrm{m}$. Results show that the environmental variation observed along the undisturbed-impacted gradient considered influences on fish assemblage structure. Both richness and diversity differences between fish assemblages are partially influenced by stream stretch orthonian order and anthropogenic impacts. ABC curves classified six stream stretches located in preserved or impacted areas as undisturbed while four stretches were classified as disturbed. This is attributed to the influence of the undisturbed habitat within the conservation unit and the presence of K- or $\mathrm{r}$ - strategist species. This type of study contributes to an understanding of the effects of aquatic environment conservation on the Brazilian Cerrado core area, where the choice of conservation areas prioritizes terrestrial over aquatic aspects.

O ribeirão João Leite está localizado no alto da bacia do rio Paraná, Brasil Central, onde drena áreas cobertas por vegetação tipo Cerrado intercaladas com áreas urbanas e agrícolas. Este estudo objetiva avaliar as mudanças na estrutura das assembleias de peixes ao longo de um gradiente ambiental (não perturbado-impactado) em trechos de dez riachos utilizando descritores ecológicos, um índice de similaridade e a relação abundância-biomassa (curvas ABC). Os peixes foram coletados durante o período da estiagem em trechos de $50 \mathrm{~m}$ utilizando a pesca elétrica. Os resultados indicam que a variabilidade ambiental observada ao longo do gradiente considerado influencia na estrutura das assembleias de peixes. As diferenças observadas entre a riqueza e diversidade das assembleias de peixes são parcialmente influenciadas pela ordem do riacho e os impactos antropogênicos. As curvas ABC classificam seis trechos localizados em áreas preservadas ou impactadas como não perturbados e quatro como perturbados. Isto é atribuído à influência do habitat preservado presente na unidade de conservação e à presença de espécies com estratégias K- ou r-. Este tipo de estudo contribui ao entendimento dos efeitos da conservação do ambiente aquático na área central do Cerrado brasileiro, onde as escolhas de áreas de conservação dão prioridade aos aspectos terrestres em detrimento dos aquáticos.

Key words: Anthropogenic impacts, Conservation unit, Meia Ponte River, Altamiro de Moura Pacheco.

\section{Introduction}

The modification of aquatic environments as a result of anthropogenic disturbances is the main threat to freshwater fish and could be the cause of the decline and extinction of many species (Buckup, 1999; Collares-Pereira \& Cowx, 2004), especially in headwater streams. This is due to the acute sensitivity of the ecological process and natural communities to atmospheric and terrestrial disturbances (Lowe \& Likens, 2005) which affect not only the local icthyofauna but also the fish assemblages in the rivers these tributaries flow into (Araújo, 1998; Meyer et al., 2007).
This modification has also been observed in water courses draining Cerrado areas undergoing intense pressure resulting from anthropogenic activities (Myers et al., 2000), such as agriculture, ranching (Klink \& Machado, 2005) and urbanization (Tejerina-Garro, 2008). These activities, in addition to others, contribute to the introduction and translocation of species, impoundment of rivers, water quality deterioration, habitat degradation and fragmentation and overexploitation (CollaresPereira \& Cowx, 2004), which are responsible for the decrease of species (Olivieiri \& Vitalis, 2001), including fish.

Anthropogenic disturbances can intervene in the hydrological patterns of the basin (Ward, 1998) and modify the

${ }^{1}$ Master Program in Ecology and Sustainable Production, Pontifícia Universidade Católica de Goiás, Campus II. Av. Engler, s/n, Jardim Mariliza, 74605-010 Goiânia, GO, Brazil. alesandra dias@hotmail.com

${ }^{2}$ Centro de Biologia Aquática, Pontifícia Universidade Católica de Goiás, Campus II. Av. Engler, s/n, Jardim Mariliza, 74605-010 Goiânia, GO, Brazil.garro@pucgoias.edu.br 
physical attributes of the aquatic habitat (Karr, 1981; Melo et al., 2003), which include such biological features (Maddock, 1999) as its riparian vegetation. This influences the structure and composition of the fish assemblages. The transformation of riparian vegetation into grasslands influences the availability of aquatic micro-habitats for fish (Ferreira \& Casatti, 2006a; Gomiero \& Braga, 2006), since it leads to an increase in the incidence of light and the exclusion of certain alimentary resources (Smith et al., 2003) or a reduction in the number of sites for reproduction (Serra et al., 2007). In turn, the removal of vegetation in the drainage basin leads to erosion which increases water turbidity and makes the detection of fish predators more difficult (Miner \& Stein, 1996). It also leads to prey developing behaviour to avoid fish predators (Gregory, 1993). In addition, the removal of the riparian vegetation favors water temperature increases which influence the fish assemblages structure (Waite \& Carpenter, 2000) via the influence of temperature on fish metabolism (Giller \& Malmqvist, 1998). An increase in sediments diminishes the diversity and integrity of aquatic communities, thus upsetting the availability of fish shelters which serve as protection against birds and mammal predators (Ferreira \& Casatti, 2006a) or are used for feeding and spawning (Berkman \& Rabeni, 1987).

Domestic effluent deposited in the water diminishes the water oxygen content (Smith \& Barrela, 2000; Daniel et al., 2002; Ferreira \& Petrere-Jr., 2007) thereby killing certain organisms or benefiting others, such as those of Poecilia reticulata (Lewis Jr., 1970; Poulin et al., 1987; Vieira \& Shibatta, 2007; Casatti et al., 2006a,b).

On the other hand, in undisturbed aquatic environments a greater fish richness and a relatively evenly distributed species abundance is expected (Magurran \& Phillip, 2001), both favored by the complexity and heterogeneity of the aquatic environment (Gorman \& Karr, 1978; Tonn \& Magnuson, 1982; Horan et al., 2000; Lima-Jr. et al., 2006). Furthermore, it was seen that fish species diversity is high in undisturbed water courses with riparian vegetation cover, because they present a greater availability of habitats, low oscillation of environmental conditions (Wichert \& Rapport, 1998; Stauffer et al., 2000; Vondracek et al., 2005; Gomiero \& Braga, 2006) and availability of fish food, such as aquatic insects (Winemiller et al., 2008).

Environmental disturbances also affect the aquatic community structure in terms of abundance and biomass, both measured by the ABC curves method. This method has a theoretical background related to $\mathrm{r}$ - and $\mathrm{K}$ - selection. That means that in undisturbed states the community is supposed to be dominated by K- selected species characterized by large, slowgrowing and late maturing bodies. In this case the biomass curve lies above the abundance curve. In disturbed states there is a dominance of $r$ - selected species displaying small fast-growing bodies and opportunistic comportment, expressed by the biomass curve lying below the abundance curve (Yemane et al., 2005).

$\mathrm{ABC}$ curves were initially used to detect the influence of anthropogenic activities, represented by pollution, on marine macrobenthic communities (Warwick, 1986). However, this method is sensitive to changes in freshwater fish community structures resulting from modifications of the physical habitat and pollution (Coeck et al., 1993), pollution, engineering and overfishing (Penczak \& Kruk, 1999), disturbed water and habitat (Casatti et al., 2006a), fisheries (Kantoussan et al., 2007) and the introduction of exotic fish species (Rocha \& Freire, 2009). However, one must realise that ABC curve analysis may be biased by a large influx of recruitment of dominant species (Yemane et al., 2005).

The aim of this study is to asses changes of the fish assemblages structure along an undisturbed-impacted gradient in streams of the upper Paraná River basin, Central Brazil.

\section{Material and Methods}

\section{Study area}

The João Leite River is a tributary of the Meia Ponte River in Goiás State, upper Paraná River basin, Central Brazil (Fig. 1). It drains an area of $751.51 \mathrm{~km}^{2}$ covered by Cerrado vegetation and Atlantic Forest. Its springs are situated in the Serra do Sapato Arcado, northwest of the Ouro Verde municipality (Galinkin, 2003) and it is located in the Central Plateau, represented by the geologic sub-units of upper TocantinsParanaíba and Lower Goiânia Plateaus. The climate is hot and sub-humid with six-month dry season (April - September) and about $80 \%$ of the rain falling between November and March (Galinkin, 2003).

The human occupation of this basin started in the XIX century with the development of the towns of Nerópolis and Anápolis (Nascimento, 1998). The basin partially drains the municipal regions of Goiânia, Anápolis, Nerópolis, Goianápolis, Terezópolis, Ouro Verde, Campo Limpo and the Goialândia district (Galinkin, 2003).

The ten streams sampled in this study are located in the midlower part of the João Leite River basin (Fig. 1; Table 1). The drainage areas of the Macaúba, Carapina, Cana Brava and Barreiro streams include part of the Altamiro de Moura Pacheco State Park conservation unit (PEAMP) and are named according to this location as $\mathrm{P} 1, \mathrm{P} 2, \mathrm{P} 3$, and $\mathrm{P} 4$, respectively. The $\mathrm{P} 3$ stream drainage area is located within the PEAMP, whereas the headwaters of the P1, P2 and P4 streams are outside the park. The stretches sampled are all located within the PEAMP area and range from $1^{\text {st }}$ to $3^{\text {rd }}$ order (Table 1). Their riversides are covered by riparian vegetation. The adjacent areas do not display any modifications resulting from anthropogenic activities, except for P1, P2 and P4 streams, whose bed channels run into an artificial channel upstream $(\mathrm{P} 1, \mathrm{P} 4)$ or downstream $(\mathrm{P} 2)$ from the stretch sampled. Since 1991 the PEAMP has been a total protection conservation unit created to conserve one of the last Atlantic Forests remaining in Goiás State (Fig. 1). It totals an area of 38.72 $\mathrm{km}^{2}$ (GOIÁS, 1991) split by a Brazilian highway located upstream from the P4 stretch. In view of these characteristics the stretches sampled within the PEAMP were considered preserved.

Six streams (Palmito, Onça, Unnamed Stream 3, Bandeira, Pedreira and Unnamed Stream 2) which in this study are called NP1, NP2, NP3, NP4, NP5 and NP6, respectively, are located in impacted areas (Fig. 1). Riparian vegetation exists along the stretches sampled in the NP2 $\left(2^{\text {nd }}\right.$ order $)$, NP4 $\left(3^{\text {rd }}\right)$ and NP5 $\left(2^{\text {nd }}\right)$ 


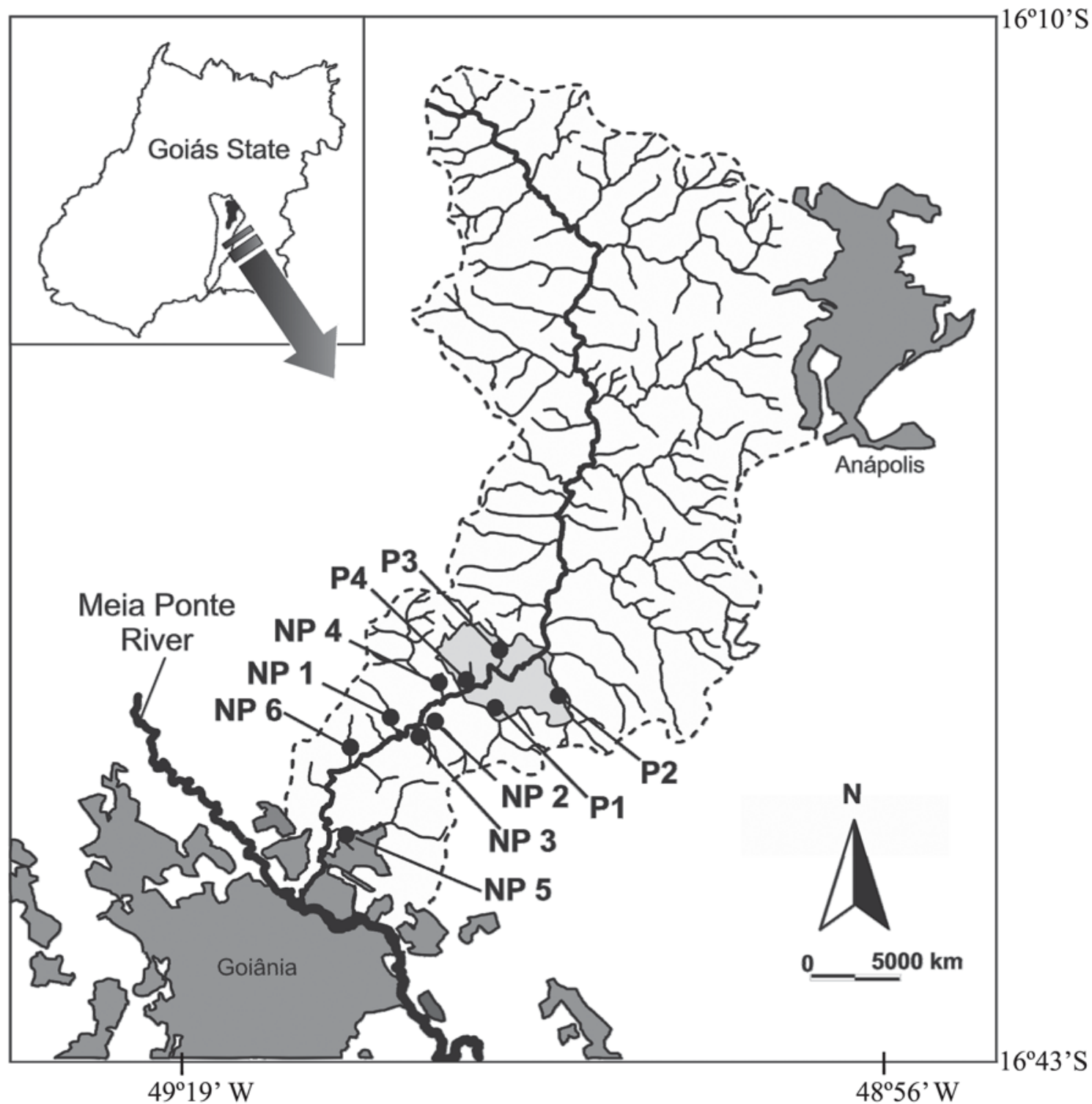

Fig. 1. Location of the streams sampled in the João Leite River basin, Goiás, Central Brazil. The broken line represents the limits of the basin. Clear grey area =Altamiro de Moura Pacheco State Park; Goiânia and Anápolis are the main cities in the basin. P1 = Macaúba; P2 = Carapina; P3 = Barreiro; P4 = Cana Brava; NP1 = Palmito; NP2 = Onça; NP3 = Unnamed Stream 3; NP4 = Bandeira; NP5 = Pedreira; NP6 = Unnamed Stream 2.

streams, but it has been substituted by pasture along the stretches of the NP1 $\left(1^{\text {st }}\right)$, NP3 $\left(2^{\text {nd }}\right)$ and NP6 $\left(2^{\text {nd }}\right)$ streams. In all the impacted stretches the natural vegetation cover of the adjacent areas has been substituted predominantly by pasture (ranching). Additionally, water is pumped for irrigation upstream from the stretch sampled in the NP4 stream, water reservoirs are present either upstream (NP1, NP4) or downstream (NP2, NP3) from the stretches sampled. There is evidence of domestic effluent release upstream from the NP5 stretch, while downstream from it there is an artificial unevenness $(>5 \mathrm{~m})$ of the stream bed and garbage (domestic and organic) is dumped. The NP5 stream is located on the border of Goiânia city urban area and near a road. On considering these impacts observed all six stretches sampled were considered impacted.

\section{Sampling protocols}

Stream stretches were sampled every two months during the dry season (April to September of 2005 and 2006) in order to eliminate any interference caused by the rains. In each stream a stretch of $50 \mathrm{~m}$ was delimited and its geographic coordinates (GPS 12 - GARMIN) obtained. Thus the same stream stretches were sampled over two dry seasons. Access conditions were a determining factor in the choice of stretches. Fishes were collected by electrofishing, an efficient technique for the capture of small fish species (Severi et al., 1995) in narrow and relatively shallow water courses (Mazzoni et al., 2000), both conditions found in the streams sampled in this study. A portable electricity generator was used (HONDA EZ1800-220 v), connected to an energy modulator, to which two electrified net rings (direct current, 
Table 1. Geo-reference of stream stretches in the João Leite River basin, Goiás, Central Brazil. Stream codes and orthonian order of the stretch sampled are indicated.

\begin{tabular}{lcccc}
\hline Stream & Code & $\begin{array}{c}\text { Orthonian } \\
\text { order }\end{array}$ & $\begin{array}{c}\text { Geographic coordinates } \\
\text { S }\end{array}$ & W \\
\hline Macaúba & P1 & 2 & $16^{\circ} 32^{\prime} 11.4^{\prime \prime}$ & $49^{\circ} 09^{\prime} 01.6^{\prime \prime}$ \\
Carapina & P2 & 3 & $16^{\circ} 32^{\prime} 00.3^{\prime \prime}$ & $49^{\circ} 06^{\prime} 50.2^{\prime \prime}$ \\
Barreiro & P3 & 1 & $1^{\circ} 31^{\prime} 14.1^{\prime \prime}$ & $49^{\circ} 08^{\prime} 45.5^{\prime \prime}$ \\
Cana Brava & P4 & 2 & $1^{\circ} 31^{\prime} 56.3^{\prime \prime}$ & $49^{\circ} 09^{\prime} 39.3^{\prime \prime}$ \\
Palmito & NP1 & 1 & $16^{\circ} 33^{\prime} 08.5^{\prime \prime}$ & $49^{\circ} 11^{\prime} 59.7^{\prime \prime}$ \\
Onça & NP2 & 2 & $16^{\circ} 33^{\prime} 02.0^{\prime \prime}$ & $49^{\circ} 10^{\prime} 52.8^{\prime \prime}$ \\
Unnamed Stream 3 & NP3 & 2 & $16^{\circ} 33^{\prime} 12.1^{\prime \prime}$ & $49^{\circ} 11^{\prime} 02.6^{\prime \prime}$ \\
Bandeira & NP4 & 3 & $16^{\circ} 31^{\prime} 47.2^{\prime \prime}$ & $49^{\circ} 10^{\prime} 50.0^{\prime \prime}$ \\
Pedreira & NP5 & 2 & $16^{\circ} 36^{\prime} 21.0^{\prime \prime}$ & $49^{\circ} 13^{\prime} 33.3^{\prime \prime}$ \\
Unnamed Stream 2 & NP6 & 2 & $16^{\circ} 33^{\prime} 36.4^{\prime \prime}$ & $49^{\circ} 13^{\prime} 30.5^{\prime \prime}$ \\
\hline
\end{tabular}

$100-600 \mathrm{~V})$ were attached. Each stretch was covered three times from downstream to upstream by three people following the protocol suggested by Esteves \& Lobón-Cerviá (2001). Captured fish were fixed in $10 \%$ formalin, and taxonomically identified, weighed and measured (standard length) in a laboratory. Specimens of each species were sent to the Museu de Ciências e Tecnologia, Pontifícia Universidade Católica do Rio Grande do Sul, Brazil, to confirm taxonomic identification.

\section{Data analysis}

Fish data was organized per stream stretch using species abundance (McCune \& Grace, 2002) and afterwards the ecological descriptors (abundance, richness, diversity, and uniformity) were calculated, using the Biodiversity Professional 2.0@ software.

a) Abundance. This is the number of individuals in each taxon.

b) Richness. This is the simplest measure of a community, namely the number of species it contains. It increases in direct proportion to the number of individuals sampled, thereby making it difficult to undertake a comparison between samples (Magurran, 2004). To circumvent this, the rarefaction method was used in which sub-samples of equal numbers of individuals were randomly removed from the total so as to arrive at a standardized comparison (Magurran, 2004). To facilitate comparison of the graphic results, the cut-off considered was the least abundance observed in the stream stretches sampled, that is, the 165 individuals found in the NP1 stream.

c) Diversity. One way of measuring diversity is to use an index, which considers the distribution of each species according to its statistical weight resulting from its relative abundance (Ricklefs, 1996). In this study the diversity of species was determined in bits/individuals using the ShannonWiener index, which is sensitive to rare species, that is, those which contain few collected individuals (Magurran, 2004). This index was calculated using the formula:

$\mathrm{H}=-\Sigma(\mathrm{p} i)(\log 2 \mathrm{p} i)$

Where:

$\mathrm{H}^{\prime}=$ information contained in the sample (bits/individual); $\log _{2} \mathrm{p} i=\log$ arithms in base 2 of $\mathrm{p} i$;

$\mathrm{p} i=$ ratio of $i$ specimen within the sample. d) Uniformity. This measure relates the diversity of the Shannon-Wiener index to the number of species and was calculated using the formula:

$$
\begin{aligned}
& \mathrm{J}^{\prime}=\mathrm{H}^{\prime} / \log _{2} \mathrm{~S} \\
& \text { Where: }
\end{aligned}
$$

$\mathrm{J}^{\prime}=$ uniformity of Pielou index;

$\mathrm{H}^{\prime}=$ diversity of Shannon-Wiener index;

$\log _{2} S=$ logarithms in base 2 of the total number of species; $\mathrm{S}=$ total number of species.

Afterwards, differences between the fish assemblages in terms of the average values of abundance, diversity and uniformity grouped by stretch stream were determined using a Kruskal-Wallis analysis followed by a post-hoc analysis of multiple comparison of the median position group using the Statistica 7.1C software.

e) Fish assemblage similarity. To determine the degree of similarity between the composition of fish assemblages, a Morisita-Horn index analysis (Magurran, 2004) was conducted and calculated using the formula:

$\mathrm{IM}-\mathrm{H}=2 \Sigma(\mathrm{an} i \mathrm{x}$ bn $j) /(\mathrm{da}+\mathrm{db})(\mathrm{aN})(\mathrm{bN})$

Where:

an $i=$ number of individuals of the $i$ species in place A;

bn $j=$ number of individuals of the $j$ species in place $\mathrm{B}$;

$\mathrm{aN}=$ number of individuals in place $\mathrm{A}$;

$\mathrm{bN}=$ number of individuals in place $\mathrm{B}$;

$\mathrm{da}=\mathrm{an} i^{2} / \mathrm{aN}^{2}$;

$\mathrm{db}=\mathrm{bnj} j^{2} / \mathrm{bN}^{2}$.

f) ABC curves. Dominance of abundance or biomass (statistics W) was calculated using the PRIMER (C) software. In the case of $\mathrm{ABC}$ curves, abundance reflects the biomass and energy available in the system, whereas the number of species reflects habitat diversity and the behavior of fish (Pinto et al., 2006). The curves classify the quality of the environment (Magurran, 2004) either as undisturbed (biomass curve overlaps that of abundance, $\mathrm{W}>0$ ) or disturbed (abundance curve overlaps that of biomass, $\mathrm{W}<0$ ).

\section{Results}

In all, 2,828 individuals were collected distributed over 41 species, 13 families and six orders (Table 2).

\section{Ecological descriptors}

Significant differences in terms of abundance $(\mathrm{H}(9, \mathrm{~N}=$ $40)=17.116 ; p=0.046)$ were observed between the stream stretches sampled, but the post-hoc analysis did not indicate any significant differences between or within stretches located in preserved or impacted areas (Table 3).

The rarefaction analysis did not clearly separate those stream stretches located in preserved areas from those in impacted areas. Elevated (NP4, 30 species; P1, 25) or low (P2, 13; NP2, 11; NP1, 11 ; NP3, 15) fish richness values were observed both in stream stretches located in both impacted and preserved areas (Fig. 2). 
Table 2. Number of fish per species collected in the streams located in preserved (P) and impacted (NP) areas in the João Leite River basin.

\begin{tabular}{|c|c|c|c|c|c|c|c|c|c|c|}
\hline \multirow{3}{*}{$\begin{array}{l}\text { ORDER } \\
\text { Family } \\
\text { Genus species } \\
\end{array}$} & \multicolumn{10}{|c|}{ Streams } \\
\hline & \multirow[b]{2}{*}{ P1 } & \multirow[b]{2}{*}{ P2 } & \multirow[b]{2}{*}{ P3 } & \multirow[b]{2}{*}{ P4 } & \multirow[b]{2}{*}{ NP1 } & \multirow[b]{2}{*}{ NP2 } & \multirow[b]{2}{*}{ NP3 } & \multirow[b]{2}{*}{ NP4 } & \multirow[b]{2}{*}{ NP5 } & \multirow[b]{2}{*}{ NP6 } \\
\hline & & & & & & & & & & \\
\hline CHARACIFORMES & & & & & & & & & & \\
\hline Anostomidae & & & & & & & & & & \\
\hline Leporinus microphthalmus & - & - & - & - & - & - & - & 1 & - & - \\
\hline Characidae & & & & & & & & & & \\
\hline Astyanax altiparanae & 14 & - & 49 & 6 & 5 & 25 & 47 & 32 & 7 & 4 \\
\hline Astyanax fascitaus & 48 & 58 & 34 & 68 & - & 42 & - & 37 & 36 & - \\
\hline Astyanax sp. 1 & 38 & 40 & 55 & 28 & - & 9 & - & 2 & 20 & - \\
\hline Astyanax sp. 2 & 6 & 9 & 1 & 4 & - & 14 & - & 15 & 2 & - \\
\hline Bryconamericus stramineus & 15 & - & 9 & 9 & - & 13 & 47 & 24 & 177 & 26 \\
\hline Characidium fasciatum & 3 & 8 & - & 4 & - & - & - & 13 & - & 5 \\
\hline Characidium gomesi & - & - & - & 1 & - & - & - & - & - & - \\
\hline Galeocharax knerii & 1 & - & - & - & - & - & 1 & - & - & - \\
\hline Knodus sp. & 4 & - & 5 & 4 & - & 7 & 95 & 27 & 133 & 90 \\
\hline Oligosarcus planaltinae & - & - & - & 2 & - & - & - & 1 & - & - \\
\hline Piabina argentea & 25 & - & 17 & 23 & - & 14 & 172 & 44 & 32 & 3 \\
\hline Planaltina myersi & - & - & - & 1 & - & - & - & - & 4 & - \\
\hline Serrapinnus sp. & 11 & 1 & - & 5 & - & - & - & 5 & 1 & - \\
\hline Curimatidae & & & & & & & & & & \\
\hline Cyphocharax modestus & - & - & - & - & - & - & - & 5 & 1 & - \\
\hline Erythrinidae & & & & & & & & & & \\
\hline Hoplias malabaricus & 3 & 1 & - & - & - & - & 1 & 2 & - & 1 \\
\hline Parodontidae & & & & & & & & & & \\
\hline Apareiodon ibitiensis & 1 & - & - & - & - & - & - & 5 & - & - \\
\hline Apareiodon piracicabae & 1 & - & - & - & - & - & - & 1 & - & - \\
\hline SILURIFORMES & & & & & & & & & & \\
\hline Callichthyidae & & & & & & & & & & \\
\hline Aspidoras lakoi & 1 & - & 2 & - & 74 & 48 & 23 & - & 4 & 12 \\
\hline Corydoras sp. & - & - & 1 & - & 62 & 11 & 23 & - & - & 8 \\
\hline Heptapteridae & & & & & & & & & & \\
\hline Cetopsorhamdia sp. & 1 & 7 & - & - & - & - & - & 5 & - & - \\
\hline Imparfinis sp. & 1 & 9 & - & 1 & - & - & - & 3 & - & - \\
\hline Phenacorhamdia sp. & 2 & 6 & - & 3 & - & - & - & 1 & - & - \\
\hline Pimelodella sp. & - & 34 & - & - & - & - & - & 2 & - & - \\
\hline Rhamdia quelen & 6 & 16 & 5 & 4 & 8 & 2 & - & 8 & 43 & 2 \\
\hline Loricariidae & & & & & & & & & & \\
\hline Hisonotus sp. & - & - & - & - & - & - & - & 3 & - & - \\
\hline Hypostomus ancistroides & - & 2 & - & 1 & 9 & - & - & 1 & 4 & 1 \\
\hline Hypostomus regani & - & - & - & - & 2 & - & 2 & - & 1 & - \\
\hline Hypostomus sp. 1 & - & - & - & - & - & - & 1 & - & 14 & - \\
\hline Hypostomus sp. 2 & - & - & - & - & 3 & - & - & 2 & 13 & - \\
\hline Rineloricaria latirostris & 1 & - & - & 1 & - & - & - & - & - & - \\
\hline PERCIFORMES & & & & & & & & & & \\
\hline Cichlidae & & & & & & & & & & \\
\hline Apistogramma sp. & - & - & - & 1 & - & - & - & - & - & 2 \\
\hline Cichlasoma paranaense & 12 & - & 3 & 8 & 1 & - & 41 & 13 & - & 9 \\
\hline Crenicichla britskii & 2 & - & - & - & - & - & - & 9 & - & 10 \\
\hline Laetacara sp. 1 & - & - & - & - & - & - & - & 6 & - & 3 \\
\hline Laetacara sp. 2 & 1 & - & - & - & - & - & - & 3 & - & 1 \\
\hline Tilapia rendalli & - & - & - & - & 1 & - & - & - & 30 & - \\
\hline CYPRINODONTIFORMES & & & & & & & & & & \\
\hline Poeciliidae & & & & & & & & & & \\
\hline Poecilia reticulata & 1 & 1 & 2 & 2 & 1 & - & 43 & 1 & 104 & 12 \\
\hline GYMNOTIFORMES & & & & & & & & & & \\
\hline Gymnotidae & & & & & & & & & & \\
\hline Gymnotus carapo & 8 & - & 3 & 1 & 2 & 2 & 13 & 20 & 19 & 54 \\
\hline Sternopygidae & & & & & & & & & & \\
\hline Eigenmannia trilineata & 2 & - & - & - & - & - & - & 15 & 1 & 4 \\
\hline SYNBRANCHIFORMES & & & & & & & & & & \\
\hline Synbranchidae & & & & & & & & & & \\
\hline Synbranchus marmoratus & - & - & - & - & - & - & 1 & - & - & 1 \\
\hline Total & 208 & 192 & 186 & 177 & 168 & 187 & 510 & 306 & 646 & 248 \\
\hline
\end{tabular}

No significant differences were observed between stream stretches in preserved or impacted areas when diversity and uniformity descriptors were considered, but there were significant differences in both fish diversity $(\mathrm{H}(9, \mathrm{~N}=40)=$ $27.731 ; \mathrm{p}=0.001)$ and uniformity $(\mathrm{H}(9, \mathrm{~N}=40)=17.394 ; \mathrm{p}=$ 0.042 ) within impacted stream stretches. Fish diversity in the 
NP1 stream (1.032 bits/individuals) differed from that of the NP4 (3.641 bits/individuals; $\mathrm{p}=0.001)$ and NP5 streams (2.914 bits/individuals; $p=0.028$; Table 3 ), whereas uniformity values presented significant differences between the NP1 (0.476) and NP4 (0.883) stream stretches $(\mathrm{p}=0.004$; Table 3$)$.

\section{Similarity of fish assemblages}

The results of the Morisita-Horn similarity analysis indicate that the fish assemblages composition in the stream stretches located in preserved areas (group I), with the exception of P4, differ from those located in impacted areas (group II; Fig. 3).

\section{ABC Curves}

The ABC curves indicated that of the stream stretches located in the PEAMP area, the P1 and P2 were undisturbed in $2005(\mathrm{~W}=0.0064 ; \mathrm{W}=0.017$, respectively) and 2006 (W= 0.127 and $\mathrm{W}=0.126$, respectively), whereas the P3 stream stretch was disturbed in $2005(\mathrm{~W}=-0.011)$ and the $\mathrm{P} 4$ in 2006 (W=-0.072; Fig. 4).

The NP1 stream stretch was disturbed in both years of the sample $(\mathrm{W}=-0.112$ in $2005 ; \mathrm{W}=-0.275$ in 2006; Fig. $5)$, whereas the NP6 stream was only disturbed in 2006 $(\mathrm{W}=-0.082$; Fig. 6). The other four streams were presented as undisturbed (Figs. 5 and 6).

\section{Discussion}

Modifications of aquatic communities in natural conditions imply the influence of abiotic variations on the abundance, species richness (Matthews, 1998), diversity and uniformity of fish assemblages (Cunico et al., 2006). Hence, these are satisfactory descriptors in evaluating the levels of environmental aquatic degradation (Casatti et al., 2006a). Thus it is presumed that undisturbed water courses present greater richness, species diversity and a relatively balanced distribution of individuals (Navas-Pereira \& Henrique, 1996; Gafny et al., 2000; Argent et al., 2003; Cunico et al., 2006; Otero et al., 2006). In this study, this partially occurs in terms of fish richness as certain stream stretches located in preserved areas present a higher richness average ( $\mathrm{P} 1,23$ species; $\mathrm{P} 4,20)$ than stretches located in impacted areas (NP6, 17; NP5, 15; NP1, 11; NP2, 11; NP3, 9 species, respectively), with the exception of the NP4 stream (26 species), where the diversity index displayed the highest value among the stream stretches sampled. The level of aquatic environmental degradation also explains the sligth similarity between the fish assemblages composition of three of the stream stretches located in preserved areas, but not of the fourth (P4), and those of stretches sited in impacted areas.

Although, it is also necessary to remember that fish assemblages are influenced by stream order. As stream order increases, the richness and total number of fish also increase (Platts, 1979). In this study stream stretches range from first to third order. The NP4 is a third order stream stretch, and thus has a larger drainage area than the other stream stretches sampled, thereby influencing species richness and the diversity of fish assemblage (Wootton, 1990; Grenouillet et
Table 3. Average and standard deviation values (in parenthesis) of abundance (n), Shannon-Wiener diversity Index ( $\left.\mathrm{H}^{\prime}\right)$ and Pielou uniformity $\left(\mathrm{J}^{\prime}\right)$ of fish assemblages sampled in stream stretches of the João Leite River. Significant values are indicated in bold ( $p$ $<0.05){ }^{a, b, c}=$ the same letter indicates significant differences between stretches resulting from post-hoc test $(p<0.05)$.

\begin{tabular}{lccc}
\hline Stream & $\mathrm{n}$ & $\mathrm{H}^{\prime}$ & $\mathrm{J}^{\prime}$ \\
\hline P1 & 52 & 2.723 & 0.787 \\
& $(23.636)$ & $(0.218)$ & $(0.027)$ \\
P2 & 48 & 2.322 & 0.763 \\
& $(16.268)$ & $(0.362)$ & $(0.101)$ \\
P3 & 46.5 & 2.012 & 0.743 \\
& $(33.689)$ & $(0.207)$ & $(0.068)$ \\
P4 & 44.25 & 2.205 & 0.703 \\
& $(28.698)$ & $(0.366)$ & $(0.089)$ \\
NP1 & 42 & $1.032^{\mathrm{a}}$ & $0.476^{\mathrm{b}}$ \\
& $(16.512)$ & $(0.195)$ & $(0.112)$ \\
NP2 & 46.75 & 1.963 & 0.765 \\
& $(22.306)$ & $(0.777)$ & $(0.172)$ \\
NP3 & 127.5 & 2.124 & 0.696 \\
& $(55.386)$ & $(0.451)$ & $(0.128)$ \\
NP4 & 76.5 & $3.641^{\mathrm{a}}$ & $0.883^{\mathrm{c}}$ \\
& $(37.890)$ & $(0.163)$ & $(0.041)$ \\
NP5 & 161.5 & $2.914^{\mathrm{b}}$ & 0.775 \\
& $(94.235)$ & $(0.370)$ & $(0.06)$ \\
NP6 & 62 & 2.358 & 0.754 \\
& $(56.833)$ & $(0.440)$ & $(0.166)$ \\
\hline $\boldsymbol{p}$ & $\mathbf{0 . 0 4 6}$ & $\mathbf{0 . 0 0 1}$ & $\mathbf{0 . 0 4 2}$ \\
\hline
\end{tabular}

al., 2004). However, this influence does not seem to apply to the other third order stretch P2.

Stream order does not explain the grater abundance and diversity of fish assemblages observed in stretch NP5 (second order) when compared to the other stretches of the same order (P1, P4, NP2, NP3, NP6). The NP5 stream stretch undergoes several different impacts (domestic effluent, artificial unevenness of the stream bed, location on the border of an urban area and near a road). Yet, this same stretch presents high diversity values. This is partially explained by the effect of species addition on local richness and diversity resulting from the introduction of fish (Sax \& Gaines, 2003; Oliveira \& Bennemann, 2005), which, in this study, were $T$. rendalli and $P$. reticulata and particularly in the NP5 stream stretch, both of which are resistant to low water oxygenation levels (Lewis Jr., 1970; Poulin et al., 1987; Beveridge \& McAndrew, 2000) and tolerant to disturbed environments when compared to native species (Buermann et al., 1997; Minte-Vera \& Petrere Jr., 2000). Additionally, it is necessary to consider that a moderate increase in pollution, represented by domestic sewage in the case of the NP5 stretch, can cause an increase in abundance without species exclusion, thereby increasing Shannon-Wiener Index values (Metcalfe, 1994).

In the case of the NP1 stream stretch, the fact that it is classified as a first orthonian order does not alone explain the low value of species richness and diversity (lowest values of all stretches sampled) observed when compared with the other first order stretch (P3), which displays increased species richness and diversity. An additional explanation for NP1 results is the landscape modifications made in its drainage area. With the exception of a part of its headwaters, its original 
vegetation cover has been substituted by grass and crops. Agricultural areas lead to channel stream siltation and give rise to erosion (Ferreira \& Casatti, 2006a), which diminishes the channel depth and benefits small benthonic fish species, such as the armored catfishes A. lakoi and Corydoras sp. (Fialho \& Tejerina-Garro, 2004), both predominant in the stream stretch NP1. Moreover, deforestation of the riparian vegetation observed in the NP1 stream stretch leads to an increase in light incidence on the water surface. According to Lowe-McConnell (1999), this propitiates the appearance of algae, one of the feeding components of the two abovementioned catfishes (Lemes \& Garutti, 2002).

In turn, the second order NP3 stream stretch presented low values of richness and fish diversity. This is partly explained by the predominance of two characins $P$. argentea and Knodus sp., which represent $52.4 \%$ of the total abundance. This predominance is related to a narrow channel (average $=$ $2.44 \mathrm{~m}$ ) in conjuction with the substitution of riparian vegetation by pastures which favor species with opportunist alimentary habits, such as, $P$. argentea (Ferreira et al., 2002) and Knodus genus species (Ceneviva-Bastos \& Casatti, 2007). Moreover, the former species is common in perturbed environments (Ferreira et al., 2002; Santos et al., 2004) and possesses diurnal alimentary habits (Fialho \& Tejerina-Garro, 2004), a characteristic which may have influenced its capture.

According to Otero et al. (2006) and Yemane et al. (2005), the $\mathrm{ABC}$ curves indicate that in an undisturbed water course, large fish represent an amount which is samall in terms of the total abundance, but sufficient in terms of biomass thus, the biomass curve graphically overlaps the abundance curve. This is the case of two of the four stream stretches (P1 and P2) present in the PEAMP area in the two years under consideration. The conserved state of the PEAMP area

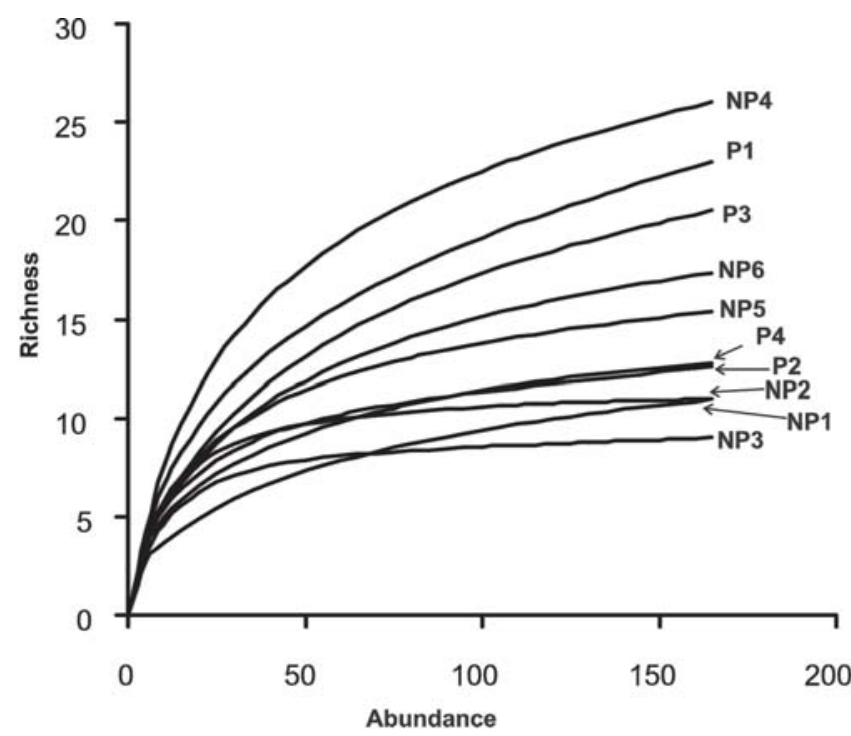

Fig. 2. Fish assemblage rarefaction plot by stream stretches. $\mathrm{P} 1=$ Macaúba P2 = Carapina; $\mathrm{P} 3=$ Barreiro; $\mathrm{P} 4=$ Cana Brava; NP1 = Palmito; NP2 = Onça; NP3 = Unnamed Stream 3; NP4= Bandeira; NP5 = Pedreira; NP6 = Unnamed Stream 2. guarantees the presence of riparian vegetation and with it food input for fish, heterogeneity of the aquatic habitat (Gorman \& Karr, 1978) and protection against water temperature oscillations (Beschta, 1997; Naiman \& Decamps, 1997; Barrela et al., 2001; Melo et al., 2004). All these seem to explain the results found for the P1 and P2 stream stretches, where the presence of fish species of specific alimentary habits, such as Cetopsorhamdia sp., Imparfinis sp., Phenacorhamdia sp., and Pimelodella sp., insectivores and benthonic catfish of the Heptapteridae family (Bockmann \& Guazzelli, 2003) indicates the high quality of the aquatic environment (Casatti et al., 2001). However, both streams are not entirely free from disturbance. Upstream from the sampled stretch bed channel of the P1 stream runs into an artificial channel (second author personal observation) and the P2 stream suffers interference from the cattle in the headwater region located outside the PEAMP area, and which remove the channel substrate (Oliveira et al., 1997).

Despite being located in impacted areas, the NP2, NP3, NP4 and NP5 stream stretches presented an undisturbed environment in the two years under consideration. In the case of the NP4 stretch stream the ABC curve results is related to the presence of large-sized fish species such as the catfish $R$. quelen, and the characins $H$. malabaricus, $L$. microphthalmus and $O$. planaltinae. The ABC curves are related to $\mathrm{r}-\mathrm{K}$ selection gradient, hence the presence of largesized fish is related to K- strategists (large bodies, slowgrowing and late maturing) and indicates that the fish community structure is not disturbed by exogenous factors (Warwick, 1986; Yemane et al., 2005), which in the case of the NP4 are represented by the impacts resulting from the main economic activities (agriculture and ranching), within its drainage basin. The presence of large species also explains the results found for the NP2 and NP5 (R. quelen) and NP3

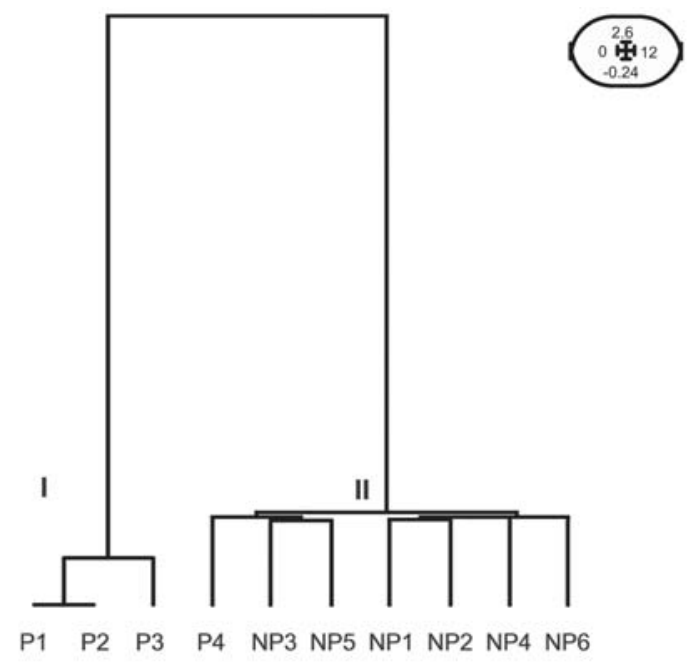

Fig. 3. Fish assemblage dendogram resulting from the Morisita-Horns analysis. Roman numerals indicate the groups and the small box the scale of variance. P1 = Macaúba; P2 = Carapina; $\mathrm{P} 3$ = Barreiro; $\mathrm{P} 4=$ Cana Brava; NP1 = Palmito; NP2 = Onça; NP3 = Unnamed Stream 3; NP4 = Bandeira; NP5 $=$ Pedreira; NP6 $=$ Unnamed Stream 2. 
2005
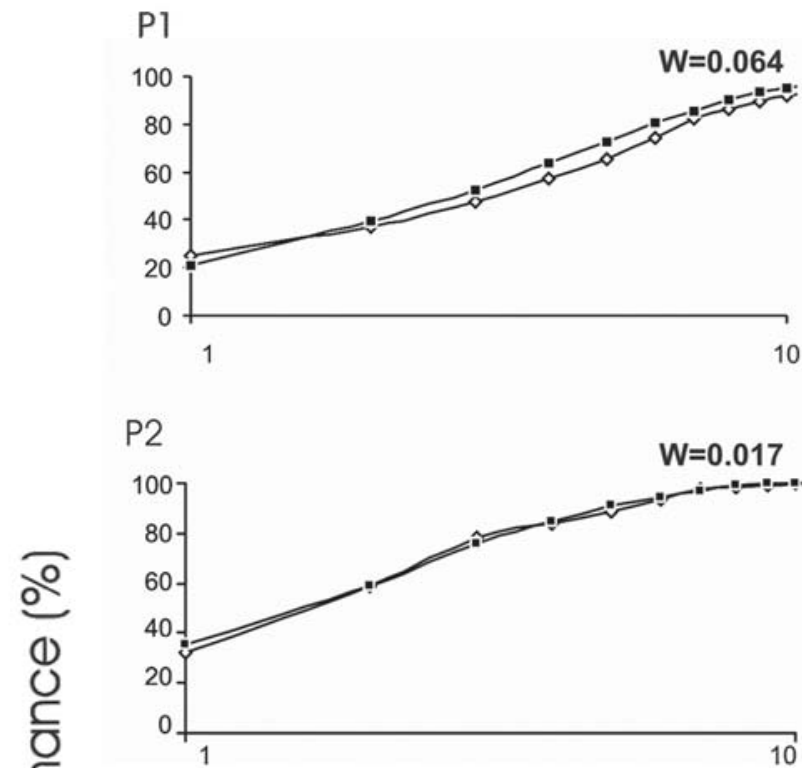

P3 $\quad \mathbf{W}=-0.011$

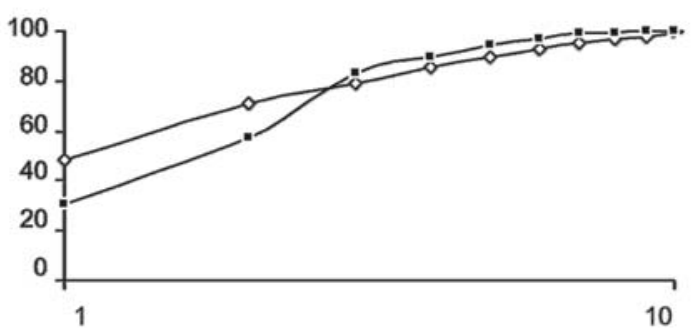

P4

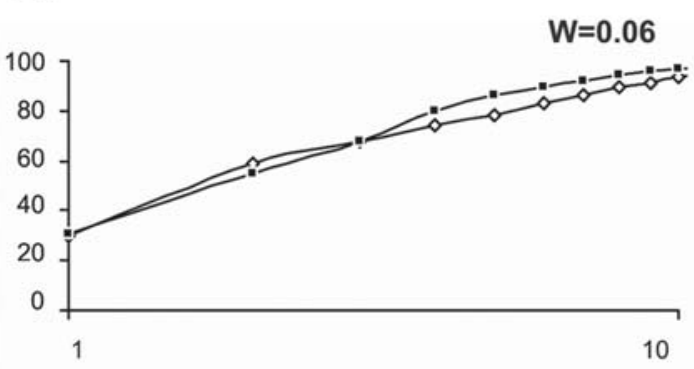

2006
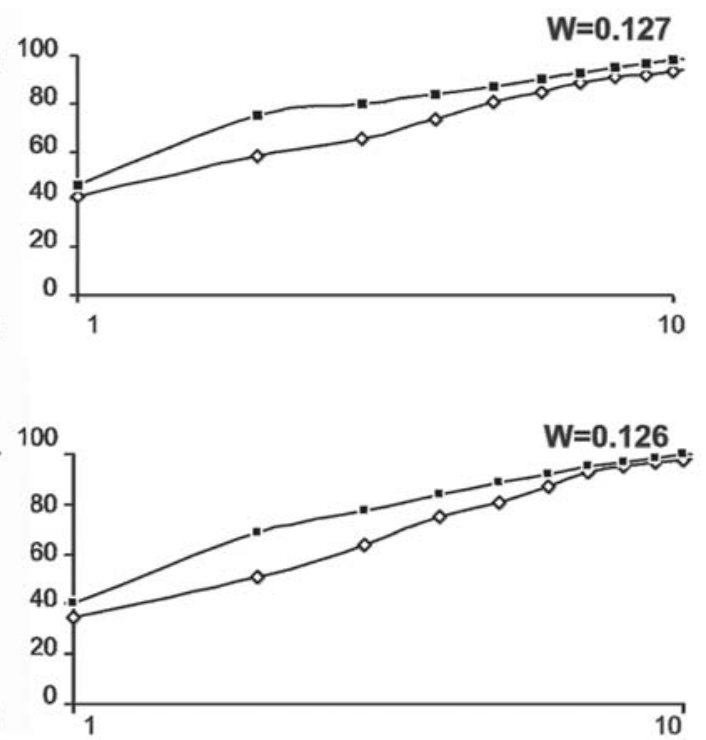

\section{Species rank}

Fig. 4. $\mathrm{ABC}$ curves per year of fish assemblages from stream stretches located in preserved areas. $\mathrm{P} 1=$ Macaúba; $\mathrm{P} 2=$ Carapina; $\mathrm{P} 3$ = Barreiro; $\mathrm{P} 4$ = Cana Brava. $\mathrm{W}=$ statistical value for each stream.

(H. malabaricus) stream stretches despite the anthropogenic impacts present, such as substitution of the riparian vegetation by pasture (NP2 and NP3), proximity of urban areas, artificial unevenness of the bed channel downstream from the sample stretch, and signs of discharge of domestic effluent (NP5).

The presence of $H$. malabaricus and $R$. quelen was also reported by Casatti et al. (2006a) in streams of the upper Paraná River basin presenting disturbed chemical conditions but less disturbed habitats and classified as undisturbed by the ABC curves method. This would suggest that H. malabaricus could be an indicator of undisturbed habitats in streams, while the presence of $R$. quelen would seem to be related to its adaptation to the adverse conditions of habitat disturbance (urban areas; Cunico et al., 2006) resulting from its biological response to wide physicochemical water oscillation (Gomes et al., 2000).

In a disturbed water course the small-sized species become dominant in terms of abundance (Casatti et al., 2006a), but not in terms of biomass. This means that there is 
2005

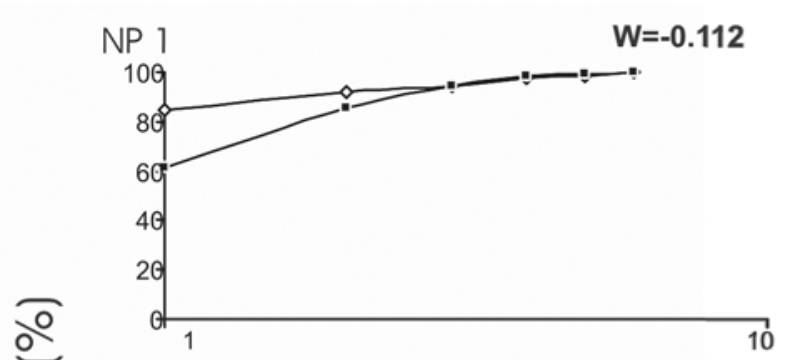

2006
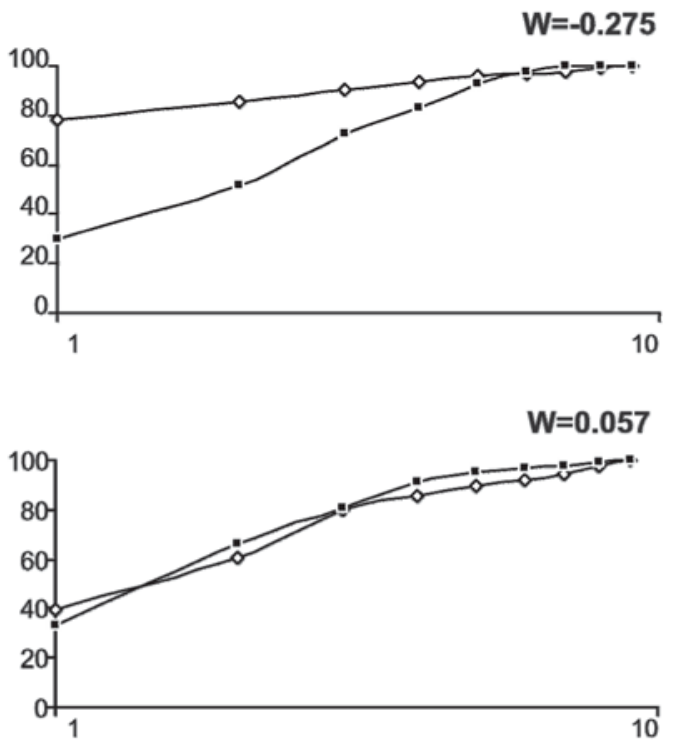

$\mathrm{W}=\mathbf{0 . 1 5 6}$

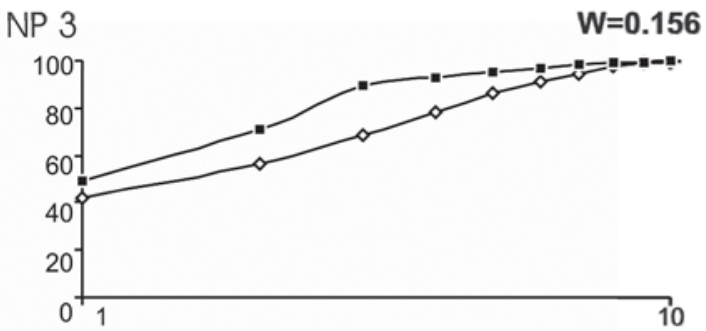

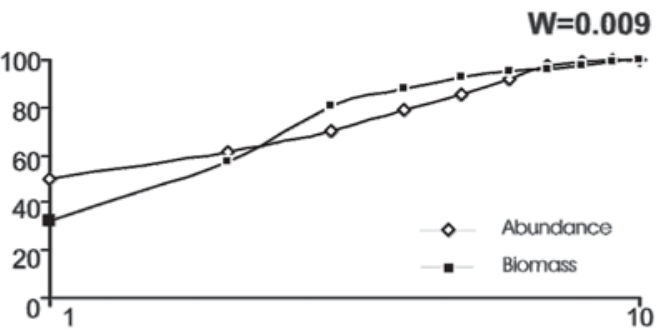

\section{Species rank}

Fig. 5. ABC curves per year of fish assemblages from stream stretches located in impacted areas. NP1 = Palmito; NP2 = Onça; NP3 = Unnamed Stream 3. W = statistical value for each stream.

an overlap of the abundance curve in relation to the biomass curve (Yemane et al., 2005; Galves et al., 2007). In this situation, the predominant species are r-strategists (small bodies, fast-growing, with opportunistic behaviour). This situation was seen in the NP1 stream in both periods considered, where two small-sized species of armored catfish (A. lakoi and Corydoras sp.) represented $81 \%$ of the total abundance. The predominance of small-sized species, the characin Knodus sp. and A. lakoi, was also seen in the NP6 stream in 2006. The stretch sampled in this stream is located in an area where the riparian vegetation has been substituted by pasture. This condition seems to favor certain fish in the NP6 stream stretch, such as the knifefish G. carapo, which feeds on insects present in the bank's submerged roots and uses this habitat as shelter against predators (Santos et al., 2004; Ferreira \& Casatti, 2006a).

The result of this study shows that the environmental variation observed along the undisturbed-impacted gradient considered influences on fish assemblage structure of the streams sampled. Both richness and diversity differences among fish assemblages are influenced partially by stream stretch orthonian order and anthropogenic impacts.

ABC curves classify six stream stretches located in preserved $(\mathrm{P} 1, \mathrm{P} 2)$ or impacted areas (NP2, NP3, NP4, NP5) as undisturbed and four stretches as disturbed (P3, P4, NP1, NP4). This is attributed to the influence of the undisturbed habitat within the PEAM (P1, P2) and the presence of K(NP2, NP3, NP4, NP5) or r- strategist species (NP1).

This type of study contributes to our understanding of the effects of aquatic environment conservation on the Brazilian Cerrado core area, where according to Tejerina-Garro (2008) the choice of conservation areas prioritizes terrestrial over aquatic aspects.

\section{Acknowledgements}

The authors are grateful to the team at the Center of Aquatic Biology and Biology Course students for collection of data in the field, to Lilian Casatti for her helpful suggestions and $\mathrm{ABC}$ curves supplementary analyses. They would also 

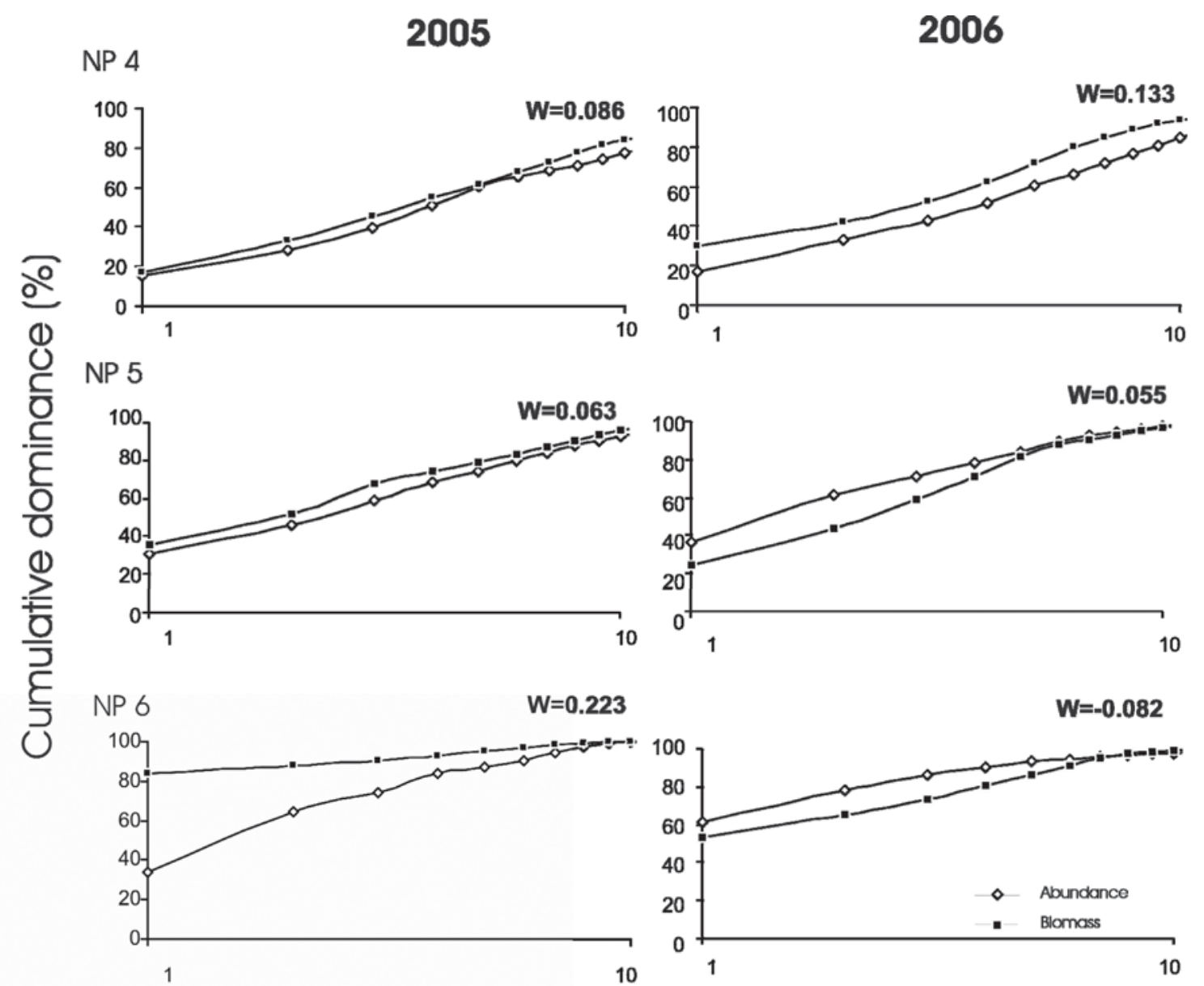

\section{Species rank}

Fig. 6. $\mathrm{ABC}$ curves per year of fish assemblages from stream stretches located in impacted areas. NP4 = Bandeira; NP5 = Pedreira; NP6 = Unnamed Stream 2. W = statistical value for each stream.

like to thank to two anonymous reviewers for their valuable suggestions, to Patrick John O'Sullivan (PUC Goiás) and Anne Mary Staunton for their revision and suggestions on English style and grammar, and the Inter-American Bank of Development and SANEAGO S.A for their financial funding, the Aroeira Foundation for its logistic support and $\mathrm{CNPq}$ for the scholarship granted to the first author.

\section{Literature Cited}

Araújo, F. G. 1998. Adaptação do índice de integridade biótica usando a comunidade de peixes para o rio Paraíba do sul. Revista Brasileira de Biologia, 58(1): 547-558.

Argent, D. G., J. A. Bishop, J. R. Stauffer, R. F. Carline \& W. L. Myers. 2003. Predicting freshwater fish distributions using landscape-level variables. Fisheries Research, 60(1): 17-32.

Barrela, W., M. Petrere-Jr., W. S. Smith \& L. F. A. Montag. 2001. As relações entre as matas ciliares, os rios e os peixes. Pp. 187-207. In: Rodrigues, R. R. \& H. F. Leitão-Filho (Eds.). Matas ciliares: conservação e recuperação. São Paulo, Edusp, 320 p.
Berkman, H. E. \& C. F. Rabenni. 1987. Effect of siltation on stream fish communities. Environmental Biology of Fishes, 18(4): 285-294.

Beschta, R. L.1997. Riparian shade and stream temperature: an alternative perspective. Rangelands, 19(2): 25-28.

Beveridge, M. C. M. \& B. J. McAndrew. 2000. Tilapias: Biology and Exploitation. Fish and Fisheries Series, 25. Massachusetts, Kluwer Academic Publishers, 532p.

Bockmann, F. A. \& G. M. Guazzelli. 2003. Family Heptapteridae. Pp. 406-432. In: Reis, R. E., O. Kullander \& C. J. Ferraris-Jr. (Eds.). Check list of the freshwater fishes of South and Central America. Porto Alegre, Edipucrs, 729p.

Buckup, P. A. 1999. Sistemática e biogeografia de peixes de riachos. Pp. 91-138. In: Caramaschi, E. P., R. Mazzoni \& P. R. Peres-Neto (Eds.). Ecologia de peixes de riachos. Rio de Janeiro, PPGE-UFRJ, 260p.

Buermann, Y., H. H. Du Preez, G. J. Steyn \& L. Smit. 1997. Tolerance levels of redbreast tilapia, Tilapia rendalli (Boulenger, 1896) to natural suspended silt. Hydrobiologia, 344(1): 11-18.

Casatti, L. J., F. Langeani, A. M. Silva \& R. M. C. Castro. 2001. Peixes de riacho do Parque Estadual Morro do Diabo, bacia do alto rio Paraná, SP. Biota Neotropica, 1(1): 1-15. 
Casatti, L. J., F. Langeani, A. M. Silva \& C. P. Ferreira. 2006a. Effects of physical habitat degradation on the stream fish assemblage structure in a pasture region. Environmental Management, 38(1): 974-482.

Casatti, L. J., F. Langeani, A. M. Silva \& R. M. C. Castro. 2006b. Stream fish, water and habitat quality in a pasture dominated basin, southeastern Brazil. Revista Brasileira de Zoologia, 23(1): 642-651.

Ceneviva-Bastos, M. \& L. Casatti. 2007. Oportunismo alimentar de Knodus moenkhausii (Teleostei, Characidae): uma espécie abundante em riachos do noroeste do Estado de São Paulo, Brasil. Iheringia, Série Zoologia, 97(1): 7-15.

Coeck, J., A. Vandelannoote, R. Yseboodt \& R. F. Verheyen. 1993. Use of the abundance/biomass method for comparison of fish communities in regulated and unregulated lowland rivers in Belgium. Regulated Rivers: Research \& Management, 8: 73-82.

Collares-Pereira, M. J. \& I. G. Cowx. 2004. The role of catchment scale environmental management in freshwater fish conservation. Fisheries Management \& Ecology, 11(3-4): 303-312.

Cunico, A. M., A. A. Agostinho \& J. D. Latini. 2006. Influência da urbanização sobre as assembléias de peixes em três córregos de Maringá, Paraná. Revista Brasileira de Zoologia, 23(4): 1101-1110.

Daniel, M. H. B., A. A. Montebelo, M. C. Bernardes, J. P. H. B. Ometto, P. B. D. Camargo, A. V. Krusche, M. V. Ballester, R. L. Victoria \& L. A. Martinelli. 2002. Effects of urban sewage on dissolved oxygen, dissolved inorganic and organic carbon, and electrical conductivity of small streams along a gradient of urbanization in the Piracicaba River basin. Water, Air, and Soil Pollution, 136: 189-206

Esteves, K. \& J. Lobón-Cerviá. 2001. Fish composition and trophic structure of a clear water Atlantic rainforest stream in Southeastern Brazil. Environmental Biology of Fishes, 62(1): 429-440.

Ferreira, A., N. S. Hahn. \& R. L. Delariva. 2002. Ecologia alimentar de Piabina argentea (Teleostei, Tetragonopterinae) nas fases pré-e pós-represamento do rio Corumbá, GO. Acta Limnologica Brasiliensia, 14(1): 43-52.

Ferreira, C. P. \& L. Casatti. 2006a. Influência da estrutura do hábitat sobre a ictiofauna de um riacho em uma micro-bacia de pastagem, São Paulo, Brasil. Revista Brasileira de Zoologia, 23(3): 642-651.

Ferreira, C. P. \& L. Casatti. 2006b. Integridade biótica de um córrego na bacia do Alto Rio Paraná avaliada por meio da comunidade de peixes. Biota Neotropica, 6(3): 1-25.

Ferreira, F. C. \& M. Petrere-Jr. 2007. Anthropic effects on the fish community of Ribeirão Claro, Rio Claro, SP, Brazil. Brazilian Journal of Biology, 67(1): 23-32.

Fialho, A. P. \& F. L. Tejerina-Garro. 2004. Peixes do Rio Meia Ponte, GO. Goiânia, Editora UCG, 105p.

Gafny, S., M. Goren \& A. Gasith. 2000. Habitat condition and fish assemblage structure in a coastal mediterranean stream (Yarqon, Israel) receiving domestic effluent. Hydrobiologia, 422/423: 319-330.

Galinkin, M. 2003. GeoGoiás 2002. Agência Ambiental do Estado de Goiás, PNUMA. Brasília, SEMARH, 272p.

Galves, W., F. C. Jerep \& O. A. Shibatta. 2007. Estudo da condição ambiental pelo levantamento da fauna de três riachos na região do Parque Estadual mata dos Godoy (PEMG), Londrina, PR, Brasil. Pan-American Journal of Aquatic Sciences, 2(1): 55-66.

Giller, P. S. \& B. Malmqvist. 1998. The biology of streams and rivers: New York, Oxford University Press, 296p.

Goiás. 1991. Governo do Estado de Goiás, Lei N ${ }^{\circ} 11.471$ de 03 de julho de 1991. Available at: $<$ http://www.gabinetecivil.goias.gov.br/ pagina leis.php?id=4780>. Accessed August, 2010 .
Gomes, L. de C., J. I. Golombieski, A. R. C. Gomes \& B. Baldisserotto. 2000. Biologia do jundiá Rhamdia quelen (Teleostei, Pimelodidae). Ciência Rural, 30: 179-185.

Gomiero, L. M. \& F. M. S. Braga. 2006. Ichthyofauna diversity in a protected area in the state of São Paulo, southeastern Brazil. Brazilian Journal of Biology, 66(1): 75-83.

Gorman, O. T. \& J. R. Karr. 1978. Habitat structure and stream fish communities. Ecology, 59(3): 507-515.

Gregory, R. S. 1993. Effect of turbidity on the predator avoindance behaviour of juvenile chinook salmon (Oncorhynchus tshawytscha). Canadian Journal of Fisheries and Aquatic Sciences, 50: 241-246.

Grenouillet, G., D. Pont \& C. Hérissé. 2004. Within-basin fish assemblage structure: the relative influence of habitat versus stream spatial position on local species richness. Canadian Journal of Fisheries and Aquatic Science, 61: 93-102.

Horan, D. L., J. L. Kershner, C. P. Hawkins \& T. A. Crowl. 2000. Effects of habitat area and complexity on Colorado River Cutthroat Trout Density in Uinta Mountain Streams. Transactions of the American Fisheries Society, 129(6): 1250-1263.

Kantoussan, J., J. M. Ecoutin, M. Simier, G. Fontenelle, O. T. Thiaw $\&$ R. Laë. 2007. The relevance of species-based indicators as a tool for evaluating the structure of exploited fish assemblages: a comparative study of two tropical lakes in Mali, West Africa. Lakes \& Reservoirs: Research and Management, 12(3): 135-148.

Karr, J. R. 1981. Assessment of biotic integrity using fish communities. Fisheries, 6(1): 21-27.

Klink, C. A. \& R. B. Machado. 2005. A conservação do Cerrado brasileiro. Megadiversidade, 1(1): 147-155.

Lemes, E. M. \& V. Garutti. 2002. Ecologia da ictiofauna de um córrego de cabeceira da bacia do alto rio Paraná, Brasil. Iheringia, Série Zoologia, 92(1): 69-78.

Lewis Jr., W. M. 1970. Morphological adaptations of Cyprinodontoids for inhabiting oxygen deficient waters. Copeia, 1970(2): 319-326.

Lima-Jr., S. E., I. B. Cardone \& R. Goitein. 2006. Fish assemblage structure and aquatic pollution in a Brazilian stream: some limitations of diversity indices and models for environmental impact studies. Ecology of Freshwater Fish, 15(1): 284-290.

Lowe, W. H. \& G. E. Likens. 2005. Moving headwater streams to the head of the class. BioScience, 55(3): 196-197.

Lowe-McConnell, R. H. 1999. Estudos ecológicos de comunidades de peixes tropicais. São Paulo, Edusp, 434p.

Maddock, I. 1999. The importance of physical habitat assessment for evaluating river health. Freshwater Biology, 41(2): 373-391.

Magurran, A. E. \& D. A. T. Phillip. 2001. Implications of species loss in freshwater fish assemblages. Geography, 24(1): 645-650.

Magurran, A. E. 2004. Measuring biological diversity. Oxford, Blackwell Science Ltd, 256p.

Matthews, W. J. 1998. Patterns in freshwater fish ecology. New York, International Thompson Publishing, 756p.

Mazzoni, R., N. Fenerich-Verani \& E. P. Caramaschi. 2000. A pesca elétrica como técnica de amostragem de populações e comunidades de peixes em rios costeiros do sudeste do Brasil. Revista Brasileira de Biologia, 60(2): 205-216.

McCune, B. \& J. B. Grace. 2002. Analysis of ecological communities. Oregon, 300p.

Melo, C. E., F. A. Machado \& V. Pinto-Silva. 2003. Diversidade de peixes em um córrego de Cerrado no Brasil central. Brazilian Journal of Ecology, 1(2): 17-23.

Melo, C. E., F. A. Machado \& V. Pinto-Silva. 2004. Feeding habits of fish from a stream in the savanna of Central Brazil, Araguaia Basin. Neotropical Ichthyology, 2(1): 37-44. 
Metcalfe, J. L. 1994. Biological water-quality assessment of rivers: use of macroinvertebrate communities. Pp. 145-170. In: Peter, C. \& E. P. Jeoffrey (Eds.). The river handbook: hidrological and ecological principles. Oxford, Blackwell Scientific Publications Press.

Meyer, J. L., D. L. Strayer, J. B. Wallace, S. L. Eggert, G. S. Helfman $\&$ N. E. Leonard. 2007. The contribution of headwater streams to biodiversity in river networks. Journal of the American Water Resources Association, 43(1): 86-103.

Miner, J. G. \& R. A. Stein. 1996. Detection of predators and habit choice by small bluegills: effects of turbidity and alternative prey. Transactions of the American Fisheries Society, 125: 97-103.

Minte-Vera, C. V. \& M. Petrere Jr. 2000. Artisanal fisheries in urban reservoirs: a case study from Brazil (Billings reservoir, São Paulo Metropolitan region). Fisheries Management and Ecology, 7: 537-549.

Myers, N., C. G. Mittermeier, G. A. B. Mittermeier, E. Fonseca \& J. Kent. 2000. Biodiversity hotspots for conservation priorities. Nature, 403(1): 853-858.

Naiman, R. J. \& H. Decamps. 1997. The ecology of interfaces: riparian zones. Annual Review of Ecology and Systematics, 28: 621-658.

Nascimento, M. A. L. S. 1998. Bacia do Ribeirão João Leite: Influência das condições ambientais naturais e antrópicas na perda de terra por erosão laminar. Unpublished Ph.D. Dissertation, Universidade Estadual Paulista, SP, 176p.

Navas-Pereira, D. \& R. M. Henrique. 1996. Aplicação de índices biológicos numéricos na avaliação da qualidade ambiental. Revista brasileira Biologia, 56(1): 441-450.

Oliveira, D. C. \& S. T. Bennemann. 2005. Ictiofauna, recursos alimentares e relações com as interferências antrópicas em um riacho urbano no sul do Brasil. Biota Neotropica, 5(1): 95-107.

Oliveira, L. G., P. C. Bispo \& N. C. Sá. 1997. Ecologia de comunidades de insetos bentônicos (Ephemeroptera, Plecoptera e Trichoptera), em córregos do Parque Ecológico de Goiânia, Goiás. Brasil. Revista Brasileira de Zoologia, 14(4): 867- 876.

Olivieri, I. \& R. Vitalis. 2001. La biologie des extinctions. Médecine Sciences, 17(1): 63-69.

Otero, M. E. B., H. L. Spach, H. A. Pichler, G. M. L. N. Queiroz, C. Santos \& A. L. C. Silva. 2006. O uso de atributos das assembléias de peixes para avaliar a integridade biótica em habitats rasos das Baías de Antonina e Paranaguá, Paraná. Acta Biológica Paranaense, 35(1): 69-82.

Penczak, T. \& A. Kruk. 1999. Applicability of the abundance/biomass comparison method for detecting human impacts on fish populations in the Pilica River, Poland. Fisheries Research, 39(3): 229-240.

Pinto, B. C., T. M. G. Peixoto \& F. G. Araújo. 2006. Effects of the proximity from an industrial plant on fish assemblages in the rio Paraíba do Sul, southeastern Brazil. Neotropical Ichthyology, 4(1): 269-278.

Platts, W. S. 1979. Relationships among stream order, fish populations, and aquatic geomorphology in an Idaho River drainage. Fisheries, 4(2): 5-9.

Poulin, R., N. G. Wolf \& D. L. Kramer. 1987. The effect of hypoxia on the vulnerability of guppies (Poecilia reticulata, Poeciliidae) to an aquatic predator (Astronotus ocellatus, Cichlidae). Environmental Biology of Fishes, 20(4): 285-292.

Ricklefs, R. E. 1996. A economia da natureza. Rio de Janeiro, Editora Guanabara Koogan S. A., 470p.

Rocha, G. R. A. \& K. M. F. Freire. 2009. Biology and dominance relationships of the main fish species in the Lake Encantada, Ilhéus, Brazil. Acta Limnologica Brasileira, 21(3): 309-316.

Santos, G. M., B. Mérona, A. F. Juras \& M. Jégu. 2004. Peixes do baixo rio Tocantins: 20 anos depois da Usina Hidrelétrica Tucuruí. Brasília, Eletronorte, 215p.
Sax, D. F. \& S. D. Gaines. 2003. Species diversity: from global decreases to local increases. Trends in Ecology \& Evolution, 18(11): 561-566.

Serra, J. P., F. R. Carvalho \& F. Langeani. 2007. Ichthyofauna of rio Itatinga in the Parque das Neblinas, Bertioga, São Paulo State: composition and biogeography. Biota Neotropica, 7(1): 81-86.

Severi, W., R. G. Hickson \& T. C. F. Maranhão. 1995. Use of electric fishing for fish fauna survey in Southern Brazil. Revista Brasileira de Biologia, 55(4): 651-660.

Smith, W. S. \& W. Barrela. 2000. The ichthyofauna of the marginal lagoon of the Sorocaba River, SP, Brazil: composition, abundance and effect of the anthropogenic actions. Revista Brasileira de Biologia, 60(4): 627-632.

Smith, W. S., M. Petrere-Jr \& W. Barrella. 2003. The fish fauna in tropical rivers: the case of the Sorocaba river basin. Revista de Biologia Tropical, 51(3-4): 769-782.

Stauffer, J. C., R. M. Goldstein \& R. M. Newman. 2000. Relationship of wooded riparian zones and runoff potential to fish community composition in agricultural streams. Canadian Journal of Fisheries and Aquatic Sciences, 57(2): 307-316.

Tejerina-Garro, F. L. 2008. Biodiversidade e impactos ambientais no Estado de Goiás: o meio aquático. In: Rocha, C., F. L. Tejerina-Garro \& J. P. Pietrafesa (Orgs.). Cerrado, sociedade e ambiente: desenvolvimento sustentável em Goiás. Goiânia, Editora UCG, 303p.

Tonn, W. M. \& J. J. Magnuson. 1982. Patterns in the species composition and richness of fish assemblages in Northern Wisconsin Lakes. Ecology, 63(4): 1149-1166.

Vieira, D. B. \& O. A. Shibatta. 2007. Peixes como indicadores da qualidade ambiental do ribeirão Esperança, município de Londrina, Paraná, Brasil. Biota Neotropica, 7(1): 57-65.

Vondracek, B., K. Blann, C. Cox, J. Nerbonne, K. Mumford, B. Nerbonne, L. Sovell \& J. Zimmerman. 2005. Land use, spatial scale, and stream systems: lessons from an agricultural region. Environmental Management, 36(6): 775-791.

Waite, I. R. \& K. D. Carpenter. 2000. Associations among Fish Assemblage Structure and Environmental Variables in Willamette Basin Streams, Oregon. Transactions of the American Fisheries Society, 129: 754-770.

Ward, J. V. 1998. Riverine landscapes: biodiversity patterns, disturbance regimes, and aquatic conservation. Biological Conservation, 83(3): 269-278.

Warwick, R. M. 1986. Anew method for detecting pollution effects on marine macrobenthic communities. Marine Biology, 92: 557-562.

Wichert, G. A. \& D. J. Rapport. 1998. Fish community structure as a mesure of degradation and rehabilitation of riparian systems in an agricultural drainage basin. Environmental Management, 22(3): 425-443.

Winemiller, K. O., A. A. Agostinho \& E. P. Caramaschi. 2008. Fish ecology in tropical streams. Pp. 107-146. In: Dudgeon, D. (Ed.). Tropical stream ecology. Amsterdam, Academic Press, 370p.

Wootton, R. J. 1990. Ecology of teleost fishes. London, Chapman and Hall, 404p.

Yemane, D., J. G. Field \& R. W. Leslie. 2005. Exploring the effects of fishing on fish assemblages using Abundance Biomass Comparison (ABC) curves. ICES Journal of Marine Science, 62(3): 374-379.

Accepted June 11, 2010

Published September 24, 2010 